\title{
The Extremely Short Story Competition: Fostering creativity and excellence in formal and informal learning contexts in the UAE and internationally
}

\author{
Peter J. Hassall \\ Zayed University, UAE
}

\section{Introduction}

Instigated in the academic year 2003/04, the Extremely Short Story Competition (ESSC) development project (Hassall 2004a; Hassall \& Ganesh, 2005) involves a creative writing competition which female Emirati university students have been keen to enter, a format for the creative writing of English in a secure context that the participants have clearly felt comfortable with, and a publishing potential which they have shown themselves enthusiastic to pursue. In addition, the ESSC has produced a body of excellent written material that is steadily influencing ensuing generations of Emirati nationals, and is now making an impact in educational institutions throughout the UAE and surrounding countries. The ESSC has also prompted parallel projects with students on the other side of the world, participating in similar creative writing competitions using the same acronym. Significantly, the ESSC has also resulted in the compilation of a creative corpus of written English text produced by groups of World English users based around ideas and topics chosen by the students themselves, or in response to the directives of the ESSC. In the UAE, the creative output of participating students has been proofread for publication and made commercially available for purchase by the Emirati and expatriate communities which comprise the population of the UAE. In 2005, the project spread via web-based technology throughout the United Arab Emirates and in 2008 the website was used to target universities, colleges and highschools from seven countries on the Arabian Peninsula: Bahrain, Kuwait, Oman, Qatar, Saudi Arabia, the United Arab Emirates and Yemen. In addition, the ESSC has recently been held for the fifth time in East Asia (http://essc.fit.ac.jp/en/ ) and has the potential to spread to other geographical regions. Data from the ESSC is being made available for cross-cultural linguistic study and, hopefully, will eventually engage the research skills of the participants themselves.

This initial ESSC UAE, and the ensuing volume Emiratia: Voices of Zayed University (Hassall, 2004b), were based around female $\mathrm{ZU}$ students' treatment of a linguistic challenge which required them to write exactly fifty words on a topic of their choice to win prizes. Student-authors also granted permission for use of their output for research and gave their approval for their submissions to be edited for publication and further dissemination. By June, 2004, the ESSC UAE had collected 250 'stories' all exactly 50 words in length, written by 150 students. These 50-word stories were compiled into a corpus of written text and were edited for inclusion in an in-house anthology (Hassall, 2004b).

The term 'story' alluded to here was used as a cover term to refer to a variety of narrative, descriptive or reflective texts of exactly 50 words in length which the students might wish to submit, whilst ensuring comprehension even by students at an elementary level of English who might not understand more technical alternatives, such as the term 'text'. Intentional use of the term 'story' also aimed to generate a minimum of inhibition, yet allow maximum freedom of expression to the student participants. This lack of topic, genre and style restriction in the ESSC was emphasized by providing a 'gloss' in the

Hassall, P.J. (2011). The Extremely Short Story Competition: fostering creativity and excellence in formal and informal learning contexts in the UAE and internationally. Learning and Teaching in Higher Education: Gulf 
promotional materials for the competition (Figure 1), which described an extremely short 'story' as being 'fact or fiction'; 'poetry or prose'. In order to encourage student-authors to refer to their own personal situation, it was indicated that even words which were 'nuss-u-nuss' (meaning 'half-and-half' and suggesting half Arabic/half English), would be permitted in entries to the competition, thus strengthening the likelihood that student-authors would refer to their own environs and lives in the $\mathrm{UAE}$, in preference to fictional characters inhabiting imaginary places in distant Europe or the United States. Note that in earlier projects with groups of students from Zayed University (see Hassall, 2004c), participants had identified as unfamiliar concepts relating to World Englishes, such as 'Gulf English'; hence it was assumed that further explicit spoken elucidation might be required to elicit authentic personal responses from the participants.

\section{Win Great Prizes and Get Published with the Extremely Short Story Competition}

All you need to do is write anything you want to write about. You can write fact or fiction, poetry or prose, or even things that are 'nuss-u-nuss'. Use the Word Count on your computer to check. Remember the title and author's name are extra.

There are 50 words here.

Figure 1: Promotional PowerPoint slide to publicize the ESSC on the Abu Dhabi and Dubai campuses of Zayed University (Hassall, 2006a)

From February to May 2004, the ESSC was held on the ZU Abu Dhabi (AUH) campus and the ZU Dubai (DXB) campus. Presentations of entries submitted to date were displayed on notice-boards and on LCD screens via PowerPoint slideshows to showcase students' successful attempts at writing 50-word stories and to motivate other students to write additional stories themselves. At the first ESSC awards event held in June at the Zayed University campuses in Abu Dhabi and Dubai, J. Maher, Director of the British Council UAE, presented four first prizes of digital cameras. In addition, copies of the Emiratia anthology were distributed to all 150 student authors who had contributed to the ESSC. The title of the anthology of 50-word short stories, "Emiratia", as explained in the preface to this book, was intended to reference Emirati identity and Emirati females; the term appears to have the potential to be meaningful in both Arabic and English. The printing of this anthology was funded by the Zayed University English Language Centre under the leadership of the then Director, Bryan Gilroy.

In the UAE there is a real scarcity of published creative writing in English by Emiratis, male or female, which has not been translated from Arabic $^{1}$. In a country which aspires to its citizens' developing high levels of competence in English, this may appear something requiring remediation as there is a wealth of metaphor, analogy, vocabulary and grammatical construction in creative English language which, as well as enriching the fictional landscape, is also transferable to expository and non-fictional genres. The publication and ultimate distribution of the Emiratia volume has gone some way to resolve this shortfall, by providing excellent written material authored by Emirati national students involving concerns emanating directly from their personal experiences. If considered necessary, each story was carefully

Hassall, P.J. (2011). The Extremely Short Story Competition: fostering creativity and excellence in formal and informal learning contexts in the UAE and internationally. Learning and Teaching in Higher Education: Gulf 
proofread to make it suitable for publication, whilst retaining the original import of the text. Emiratia provides accessible English texts written by Emirati citizens which serve as high-quality models for other nationals to develop and extend. For non-UAE citizens, distribution of the Emiratia volume provides fascinating insights into a group of participants who are becoming increasingly active on the world stage. The stories in Emiratia have also provided models of English language use outside native English-using countries and have influenced English as a Foreign Language/English for Academic Purposes [EFL/EAP] student-authors with very different cultural backgrounds, residing in Korea, Japan, China and Russia encouraging them to produce parallel contributions in a fresh literary genre which has significant potential for publication and research.

\section{Origins of the ESSC in an English native-user context}

The first anthology of 50 word stories to be compiled was aimed at native speakers of English residing in the United Kingdom, and was devised by the well-known science fiction and short-story author Brian Aldiss, OBE. In 1982, Aldiss held a competition in the Daily Telegraph newspaper to collect what he termed 'mini sagas'. In 1985, the Daily Telegraph Mini Saga Competition was run again in collaboration with BBC Radio 4's Today program. Fifty thousand entries were received and this led to the publication of the first anthology of mini sagas (Aldiss, 1995). This UK competition was repeated intermittently until 2001 when the fifth anthology of mini sagas (Aldiss, 2001) was published. This volume was written by native speakers of English primarily for a native-speaker readership. As may be appreciated from the mini sagas in Figure 2, a number of well-known celebrities and literary figures were specially commissioned to 'seed' these competitions in order to produce a series of publishable volumes. In Aldiss ((Ed.), 2001), these 'notables', included Carol Shields (winner of the Pulitzer Prize), Rachel Cusk (winner of the Whitbread First Novel Award), David Lammy (a government Minister and Member of the UK Parliament), many famous writers and humorists and even the lead singer from a pop group, Ray Davies of The Kinks.

Other mini saga anthologies in the same series have included 'seeded' stories written by famous personalities including John le Carré, Doris Lessing, Muriel Spark, Ralph Fiennes, Brian Patten, and Sir Harry Secombe. Royalties from sale of these mini saga volumes supported a charity running creative writing courses in remote areas of the British Isles. However, another competition held in the antipodes provided the original stimulus for the ESSC.

In 1997, the New Zealand National Radio talk-show host Bryan Edwards read out a selection of 50-word submissions to a competition organized by the program, Top of the Morning. Eventually, these were collected into a volume entitled The Top of the Morning book of incredibly short stories (Edwards, 1997). Once again, royalties from sales of this book were given to a charitable organization. Once more the competition was aimed at native speakers of English who, generally, became the writers and readers of the incredibly short stories. However, this time no use was made of stories commissioned from celebrities, perhaps because it was considered that regular exposure to the radio program, by itself, would be likely to stimulate sufficient high quality contributions for a publication. Reflecting the less established nature of a newer culture, or maybe the greater clarity required for an oral rendering over the radio, these New Zealand stories appeared less complicated and therefore more likely to be accessible to non-native users of English than their British counterparts, whether commissioned or not. Because of this, 50-word stories from this collection were incorporated into the initial presentation to the ZU Student Literature Club, following approval by the ZU Committee for Research into Human Subjects.

Hassall, P.J. (2011). The Extremely Short Story Competition: fostering creativity and excellence in formal and informal learning contexts in the UAE and internationally. Learning and Teaching in Higher Education: Gulf 


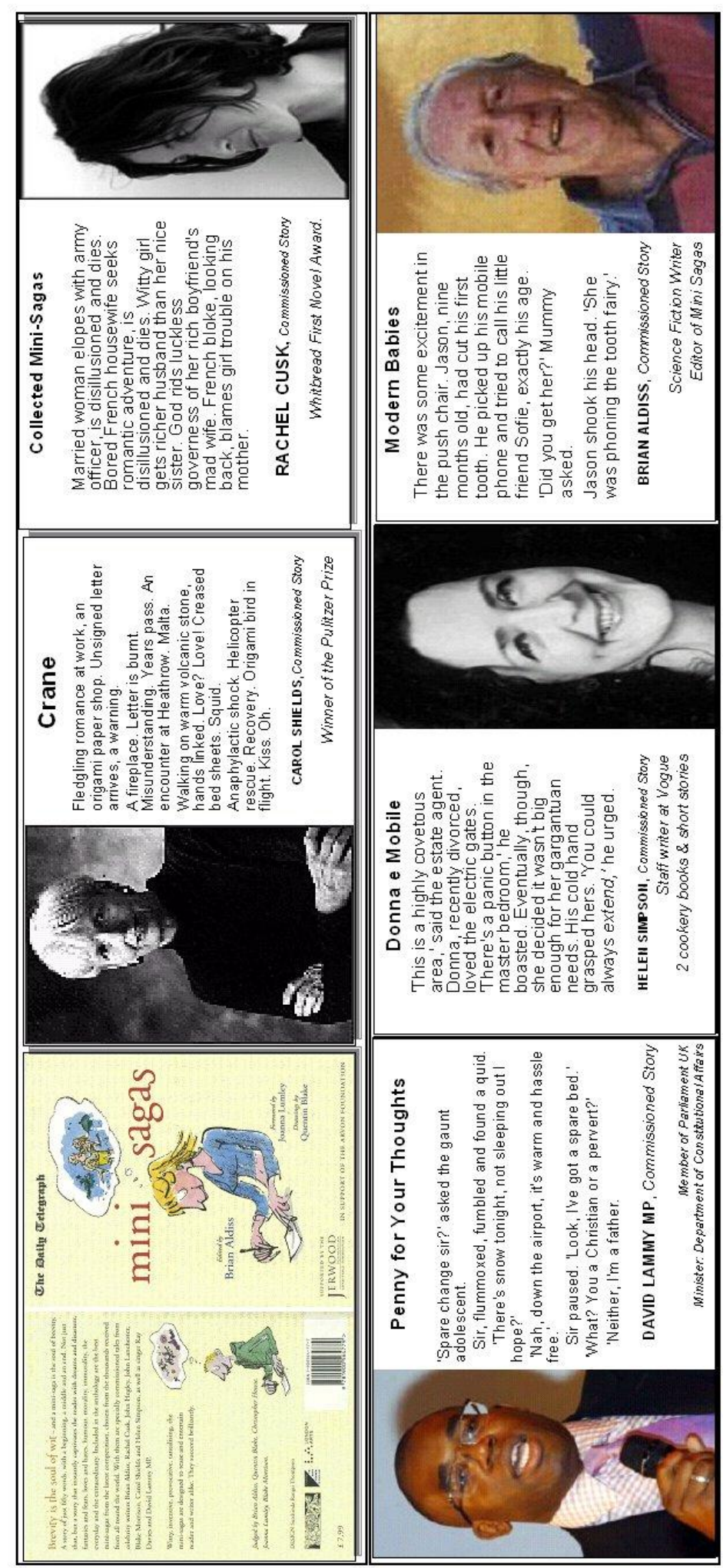

Figure 2: Extremely Short Stories commissioned to 'seed' the native-speaker Mini-Saga competition (selected from Aldiss, 2001).

Hassall, P.J. (2011). The Extremely Short Story Competition: fostering creativity and excellence in formal and informal learning contexts in the UAE and internationally. Learning and Teaching in Higher Education: Gulf Perspectives, 8(2). http://Ithe.zu.ac.ae 


\section{Origins of the ESSC in a non-native English-user context}

At the launch of the ESSC, five stories (shown in Figure 3) were read aloud to members attending the ZU Student Literature Club in Dubai. It was not disclosed that these had been selected from Edwards ((Ed.), 1997) and no hint or explanation was given as to how they had been sourced. Participating members of the club were then asked "What do these five pieces of writing have in common?" They were also asked for explication of the meaning of the stories.

Arrival, cold, feeding, warmth, elimination, changing, powdering, adoration, faltering, growing, eating, progressing, changing, yearning, palpitating, grasping, conjugation, exquisite joy, fear, flight, growing, fancying, waiting, needing, building, mating, parenting, building, working, boredom, losing, yearning, escaping, sinning, exquisite joy, pain, remorse, settling, observing arrival, feeding, changing, powdering; stability, peace, feeding, cold, departure.

(Bill Humphrey, NZ)

\section{THE BUNKER}

The President sat alone in the bunker. It was all over. The last bombs had fallen. The last nightingale had sung in Central Park. There was nothing left. He was the last man alive on Earth. There was a knock at the door...

(Terry Morrow, NZ)
It had been a smooth flight and Molly hurried into the terminal. Stopping, she searched the crowd for that familiar smile, feeling certain that she had reminded Tom to meet the five-fifteen plane. Tom, sitting at the station, looked at his watch. The fivefifteen train must be late, he thought.

(Tony Broome, NZ)

(Kay Wutzler, NZ)

"For the first trial we'll only revert one minute," Potter said.

Inside the time machine Barlow nodded.

Potter threw the switch. After one minute Barlow looked out of the time machine at Potter.

"For the first trial we'll only revert one minute," Potter said.

Inside the time machine Barlow nodded.

(Tony Girling, NZ)

Figure 3: 50-word 'Incredibly Short Stories' read out to students at the ZU Literature Club to launch the commencement of the Extremely Short Story Competition in 2004.

In addition to commenting on the shortness of the pieces, the students provided the following titles corresponding to the stories in Figure 3:

Birth, Life and Death Mistaken Meeting

The End of the World The Frog Prince \& the 50-word stories

Hassall, P.J. (2011). The Extremely Short Story Competition: fostering creativity and excellence in formal and informal learning contexts in the UAE and internationally. Learning and Teaching in Higher Education: Gulf 


\section{Stuck Inside a Time Machine}

Following the initial session, Literature Club students were given the challenge to enter the ESSC by submitting 50-word stories by e-mail to the ZU Student Literature Club, with the guarantee that their anonymity would be maintained, if they so wished, in the event of their story being published and/or used for research.

This implementation of this contest was highly successful, with increasing numbers of students entering the ESSC and submitting their stories electronically, either with the guidance of their teachers or completely independently. Workshops and information meetings were held on both campuses to introduce the competition and emphasize that the role of the teachers was to facilitate understanding of the technology and the rules of the ESSC, but not to interfere with the students' creativity, since contestants were required to sign a declaration confirming their sole authorship. The ZU Student Literature Club checked all the stories were exactly 50 words long, collected them together and sent them for proofreading and presentation in prominent places on campus using hard-copy printouts and electronic display. Mimicking the success of the New Zealand Radio Show Top of the Morning, the Zayed University Campus Radio Station, ZU Radio, broadcast over the internet and promoted the ESSC by reading Extremely Short Stories in gaps between their music selections.

\section{ESSC outcomes}

\section{Local ESSC outcomes at Zayed University}

The visual and audio campaigns had a cumulative effect and by the end of three months (May 2004) sufficient texts had been submitted ready for proofreading and publication. The Literature Club committee suggested that digital cameras might provide the most motivating prizes for a competition of this nature and the British Council offered to fund the four first prizes of digital cameras with Bookworm Bookshop presenting multiple book vouchers as further prizes.

The competition was inclusive and no students at ZU, whatever their level of English or subject specialization, were excluded from entering. The British Council in the UAE judged the competition and presented four prizes of digital cameras to the stories that they considered "highly original, reflecting the real voice of the contestant" (Hassall, 2004b). Each campus received two major prizes of cameras with book tokens for runners-up. Figure 4 shows the four first prize winning stories followed by a fifth entitled 'A Pink Sky' which was awarded a second prize along with three others. This last story was written by 'Crimson Rose', the most prolific of ESSC student-authors to date, who submitted a total of sixteen stories to this first ESSC competition.

MY WISHES

If anyone asks what I wish for?

I will tell you that I can't tell you,

because if I want to tell you my wishes

The paper of the book and the ink of the pen will finish before I finish.

Allah is the one who knows my wishes.

(FAK, AUH)

\section{LITTLE FISH, BIG FISH}

He's loving, caring, sweet and sour

He's handsome and beautiful, my knight in shining armour

He looked out for me through thick and thin

I felt like a little fish with a little fin

Can't swim without him

Can't be without him

What can I say

Hassall, P.J. (2011). The Extremely Short Story Competition: fostering creativity and excellence in formal and informal learning contexts in the UAE and internationally. Learning and Teaching in Higher Education: Gulf 


\begin{tabular}{|c|c|}
\hline & He is my daddy \\
\hline $\begin{array}{l}\text { THE PLIGHT OF THE ART STUDENT } \\
\text { Working late at night, tilting my computer screen } \\
\text { left and right... a little more blue, a little more } \\
\text { yellow... no it still isn't right! Cursing, crying to } \\
\text { ease the pain then realising that it's all in vain... All } \\
\text { this suffering... this terrible plight, all in search of } \\
\text { the perfect turquoise. } \\
\text { (SK Hamdan, AUH) }\end{array}$ & $\begin{array}{l}\text { You looked at the sky, stars and moon. You heard } \\
\text { a voice talking to the moon: "Do you feel alone?" } \\
\text { The moon said "No". Then the moon asked: "If } \\
\text { being alone makes you cry, why don't you leave } \\
\text { your loneliness?" The voice said: "Moon? Would } \\
\text { you ever leave your sky?" } \\
\text { (Voice of the Truth, DXB) }\end{array}$ \\
\hline \multicolumn{2}{|c|}{$\begin{array}{l}\text { If you ever wake up in the morning, before the sun rises, you sill see a sight for sore eyes. Before the sun } \\
\text { turns yellow, and the sky fills with soft chewy marshmallow, the sky is a soft shade of pink, a feeling so } \\
\text { beautiful that in it you'd sink. } \\
\text { (Crimson Rose, DXB) }\end{array}$} \\
\hline
\end{tabular}

Figure 4: Winning stories taken from Hassall (2004b).

All the stories submitted to the ESSC 2004 were compiled into the Emiratia anthology and published inhouse at $\mathrm{ZU}$. The stories in this volume have frequently been applauded by readers since they provide an insight into the little-known group of female Emirati university students in the UAE. They have been likened by readers to the well-known Japanese literary form of 'haiku' and a parallel Korean form known as 'shijo'. In addition, they have been compared to contemporary art forms in the visual arts, e.g. the mosaic covers of Time magazine where multiple covers are reduced electronically to function as tiles or pixels to help build up a well-known image, such as that of Leonardo's Mona Lisa: in this case the individual stories together form a coherent 'fractal' picture of students' concerns and interests.

No stories were commissioned for the ESSC UAE. Also, unlike the Aldiss anthologies, no time was spent sorting the stories into categories for the 'Emiratia' anthology. This was not undertaken because it was considered that such categorization was not always justifiable and even if it were, such thematic divisions would tend to take away the surprise, serendipitous element of the stories which comprised part of their collective delight. Instead, arranged alphabetically by title (or by first line if the title was absent), these stories contribute individually to the whole anthology, characterizing the group of students who authored them. Although written by students at Zayed University, equally important is the fact that these extremely short stories are written in English by young Muslim Emirati women. As may be appreciated by a visit to bookshops in the UAE and confirmed by electronic searches, there is not a great deal of creative published material written in English by Emirati authors, and even less written by young female Emiratis. From earlier conversations with more articulate members of the female Zayed University student body (Hassall, 2004c), it is known that English may be used in thoughtful and imaginative ways by ZU students and by the wider Emirati community when speaking or writing in private contexts. However, until publication of 'Emiratia', access to this kind of Emirati material in English has not been readily accessible in published form. This shortage of published English written by Emiratis has created a vicious circle whereby young UAE citizens have few contemporary models of English published by their peers and are therefore seldom able to emulate such models to commence building a literature in English. It was envisaged that publication and distribution of 'Emiratia' might interest those, including Emirati nationals themslves, who are keen to find out about the thoughts,

Hassall, P.J. (2011). The Extremely Short Story Competition: fostering creativity and excellence in formal and informal learning contexts in the UAE and internationally. Learning and Teaching in Higher Education: Gulf 
dreams and aspirations of Emirati women and that this might also provide authentic samples of English created by Emiratis on which potential authors might build. As the first ESSC poster session at an international conference (Hassall \& Ganesh, 2005) explained, 150 authors at Zayed University invested time and effort submitting their contributions to their ESSC in order that their work could be published to help build the foundations for literacy and literature in the United Arab Emirates.

\section{Wider dissemination of the ESSC}

Following the in-house publication of the Emiratia anthology, in November 2004 the editor was invited to Seoul, Korea to introduce the Emirati students' 50-word short stories and the ESSC project to the Asia TEFL International Conference. At this conference academics showed interest in running parallel competitions at leading universities and tertiary institutions in a number of countries. K. McLaven, Director of English Language Services at the British Council, Korea saw the potential for running the ESSC with students studying English at the British Council in Seoul.

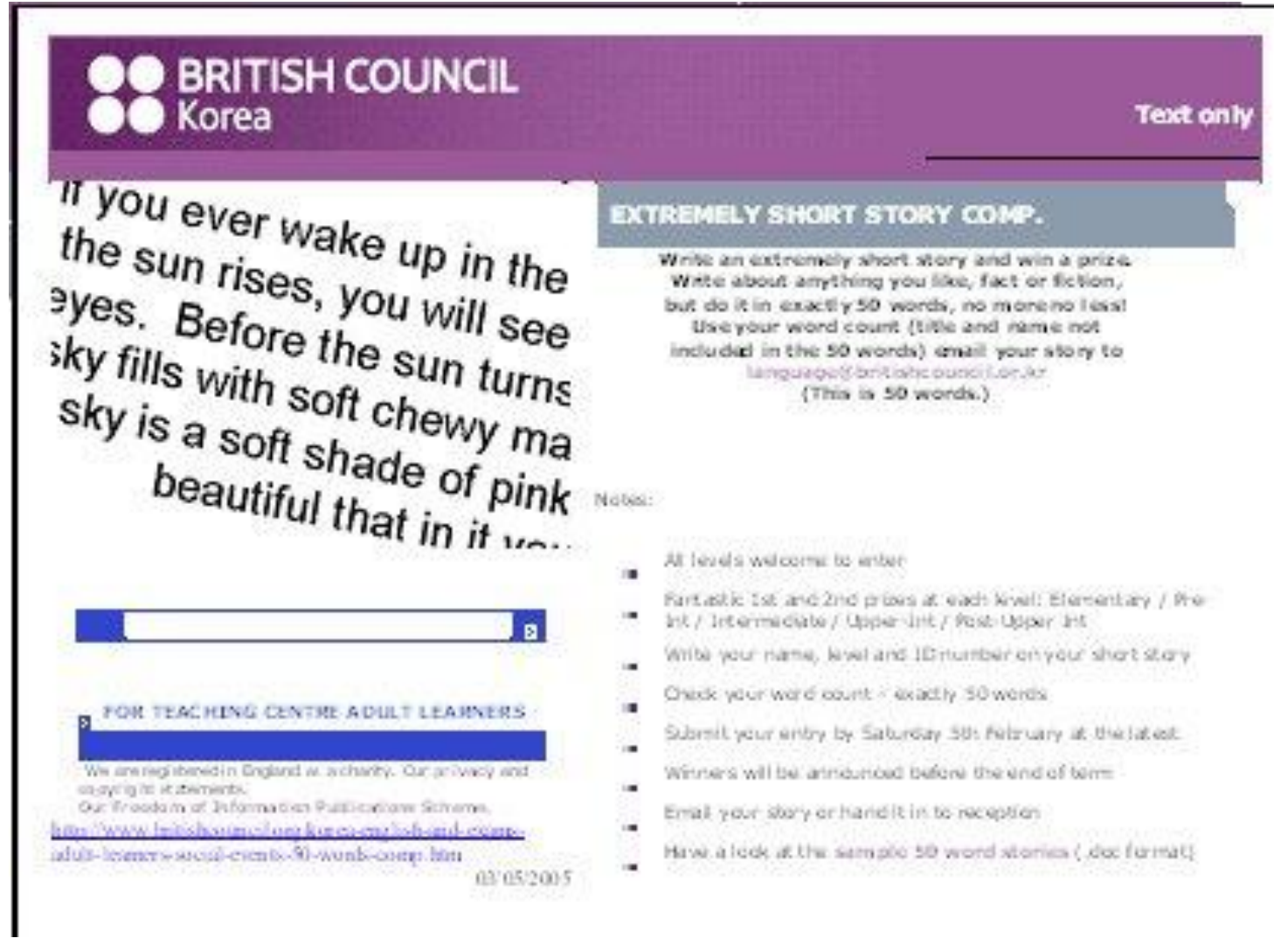

Figure 5: Zayed University Extremely Short Story displayed on the British Council Korea website (2004).

As shown in the sample screenshot in Figure 5, Extremely Short Stories created by female Emirati authors were used on the British Council Korea website both as promotional material and as example materials to inspire Korean students. Feldhusen (1994) identifies leaders as people who influence others either directly or indirectly; and these Emirati women were indeed taking steps in the direction of leadership by influencing others in the Far East, including Korea. Other sample stories from the UAE are shown on the same site at http://www.britishcouncil.org/sample_stories.doc .

Hassall, P.J. (2011). The Extremely Short Story Competition: fostering creativity and excellence in formal and informal learning contexts in the UAE and internationally. Learning and Teaching in Higher Education: Gulf 
In 2005, the ESSC Editor was invited to talk about this new edition of the anthology on the Talking Books program on Dubai Eye radio (103.8 FM), to make the ESSC and Emiratia better known in the UAE. Further international presentations ensued at Asia TEFL in China (Hassall, 2005) and at the International Association for World Englishes (IAWE) Conference in Japan (Hassall, 2006c). These led to the ESSC being adopted by Professor Noboyuki Honna, President of the Japanese Association For Asian Englishes (JAFAE). This 'export' by Hassall and 'import' by Honna is documented in Hassall (2006d) and Takeshita (2006). Under the leadership of Emeritus Professor Honna, of Aoyama Gakuin University Tokyo, the ESSC Japan has, at the time of writing, been administered by JAFAE five times at universities and high schools in Japan (http://essc.fit.ac.jp/en/). The 2nd ESSC 2007 Japan allowed Chinese students from the northern region of China, surrounding Harbin, to enter the competition alongside Japanese students. The 3rd ESSC Japan encouraged Russian students from Vladivostok to enter. Additionally, the 4th ESSC Japan welcomed submissions from South Korea. The ESSC Editor in the UAE has been made an honorary judge of the JAFAE ESSC, together with Professor Paul Kei Matsuda of Arizona State University, Founding Chair of the Symposium on Second Language Writing and Committee on Second Language Writing.

The first Zayed University ESSC anthology Emiratia: World English Voices of Emirati Women is now available for purchase by 'publication on-demand' in Japan. A more typically Japanese cover has been added along with a translation of the original preface and an introduction in Japanese written by Professor Noboyuki Honna and Professor Yuko Takeshita. Emiratia is presented to Japanese students as an introduction and guide to the ESSC in Japan. Thus, if interested in reading 50-word stories written by Zayed University students in English, it is now possible to go East and purchase a Japanese edition of the Emiratia anthology. Outstanding examples of ESSC stories written in English by Japanese students in Japan together with essays on the ESSC published in the journal Asian Englishes may be viewed at http://essc.fit.ac.jp/en/

In 2007, Hassall \& Hassall (unpublished) edited a book of Japanese ESSC stories written by Japanese students. This ESSC anthology of Japanese ESSC stories entitled Rays of the Rising Sun: World English Voices of Japan is being supplemented with illustrations and hopefully will be published in the near future to raise money for the Japanese Earthquake and Tsunami Relief Fund.

The Japanese Association For Asian Englishes (JAFAE) has also published a bilingual e-book comprising texts selected from the first JAFAE ESSC competitions 2005- 2009. These Extremely Short Stories written in English by non-native students of English in the Far East have been translated into the Japanese language and a commentary added (also written in Japanese), in order to make the ESSC accessible to the Japanese language-using public in Japan and throughout the world (Takeshita \& Tanaka, 2010).

\section{Consolidation of the ESSC in the UAE and the wider Arabian Peninsula Region}

To compile a more substantial corpus from the UAE and to collect sufficient 50-word stories for a further volume representative of the entire UAE nation, new sponsors were found to support a more extensive ESSC and a web-page was constructed at Zayed University. In addition, workshops were held in association with influential faculty and administrators at leading tertiary institutions, namely United Arab Emirates University (UAEU), Higher Colleges of Technology (HCT) and Zayed University (ZU) were contacted to encourage and support their students' submitting 50-word stories to the ESSC website. There was no necessity for these institutions to provide language support specifically for this undertaking, as it was the students' individual creations that were being sought, no matter what their level of English. What was needed was the enthusiasm generated by teachers and managers to motivate the contributors to become more independent and confident in their ability to share their creative work using a web-based submission procedure. Held under the patronage of His Excellency Sheikh Nahayan

Hassall, P.J. (2011). The Extremely Short Story Competition: fostering creativity and excellence in formal and informal learning contexts in the UAE and internationally. Learning and Teaching in Higher Education: Gulf 
Mabarak Al Nahayan, Minister of Higher Education and Scientific Research and President of Zayed University, the aim of this national competition was to be inclusive and to promote cooperation between institutions. Hence, the system which had been used to identify students attending the ZU Dubai campus from those attending the ZU Abu Dhabi campus was maintained. Thus in the original ESSC one of the winning students identified herself as 'Crimson Rose, DXB' (where DXB stands for 'Dubai'), whereas another student identified herself as 'SK Hamdan, AUH' (where AUH refers to 'Abu Dhabi'). This abbreviation is very familiar to expatriate faculty throughout the UAE as, in addition to identifying two of the major cities of the UAE, these are the International Air Transport Airport (IATA) codes for Dubai and Abu Dhabi airports. In the UAE, six sets of IATA abbreviations apply to the six major airports and the six major centers of population which provide government tertiary education for Emiratis, both male and female. These IATA codes (see below) were used as student-authorship identifiers rather than city or institution names, as they provide consistency (all being three letters in length) and do not promote competition at the institutional level:

AAN (Al Ain); AUH (Abu Dhabi); DXB (Dubai); FJR (Fujairah); SHJ (Sharjah); RAK (Ras Al Khaimah).

The web-based ESSC (http://50words.org) was held throughout the UAE in 2005/06. This involved participation of students from all the Women's and Men's Colleges of the Higher Colleges of Technology throughout the UAE, UAE University in Al Ain and Zayed University in Abu Dhabi and Dubai. This resulted in a further ESSC anthology. Entitled Pearls of Emirati Wisdom: World English Voices of the UAE (Hassall, 2007a), this anthology contains 1,000 Extremely Short Stories authored by 500 male and female Emirati nationals. In order to promote interest in the ESSC and arouse interest in the creative English being used by Emiratis, a complimentary copy of the earlier Emiratia anthology was distributed to each of the five hundred students who contributed to the competition. By distributing free copies of Emiratia to the contributors of the ESSC UAE an effort was made to reach into the homes of Emirati students. An effort was also made to make an impact on the general English-reading public (Emirati and expatriate) in the UAE. This was achieved by design of a newspaper column displaying Extremely Short Stories which appeared every day on the leisure pages of the City Times supplement of the national English language newspaper Khaleej Times. This column, entitled Emirati voices of the UAE, showed three stories taken from the Emiratia and Pearls of Emirati wisdom ESSC anthologies, and appeared daily for three years.

Following a successful ESSC UAE 2005/06, a further web-based Extremely Short Story Competition throughout the UAE was planned. This time the US State Government Middle East Partnership Initiative (MEPI) was sourced as the major sponsor. The sponsor was interested in student-authors writing on a topic decided in advance. Negotiation proceeded with MEPI and the author's suggestion of "Facets of Emirati women in the twenty-first century" was accepted. This time the Extremely Short Story Competition was supplemented by photography specifically commissioned from the Department of Art and Design at Zayed University under the tutorship of J. Lugosi. This was augmented by photographs taken by the ZU students of Y. Sun, J. Bellotto and also submissions to the 'Noor Ali Annual Photographic Competition' (with individual students' written agreement), which had been run earlier that year by $D$. Burns of the Zayed University Department of Communication, together with photographs of Zayed University taken in-house by R. Abdul Jaber.

The resulting combination of ESSC texts and photographs were put together to comprise an intriguing exhibition of 50-word stories and artistic photographs which was exhibited at the ESSC UAE Awards Evening 2007 (Figure 7).

Hassall, P.J. (2011). The Extremely Short Story Competition: fostering creativity and excellence in formal and informal learning contexts in the UAE and internationally. Learning and Teaching in Higher Education: Gulf 


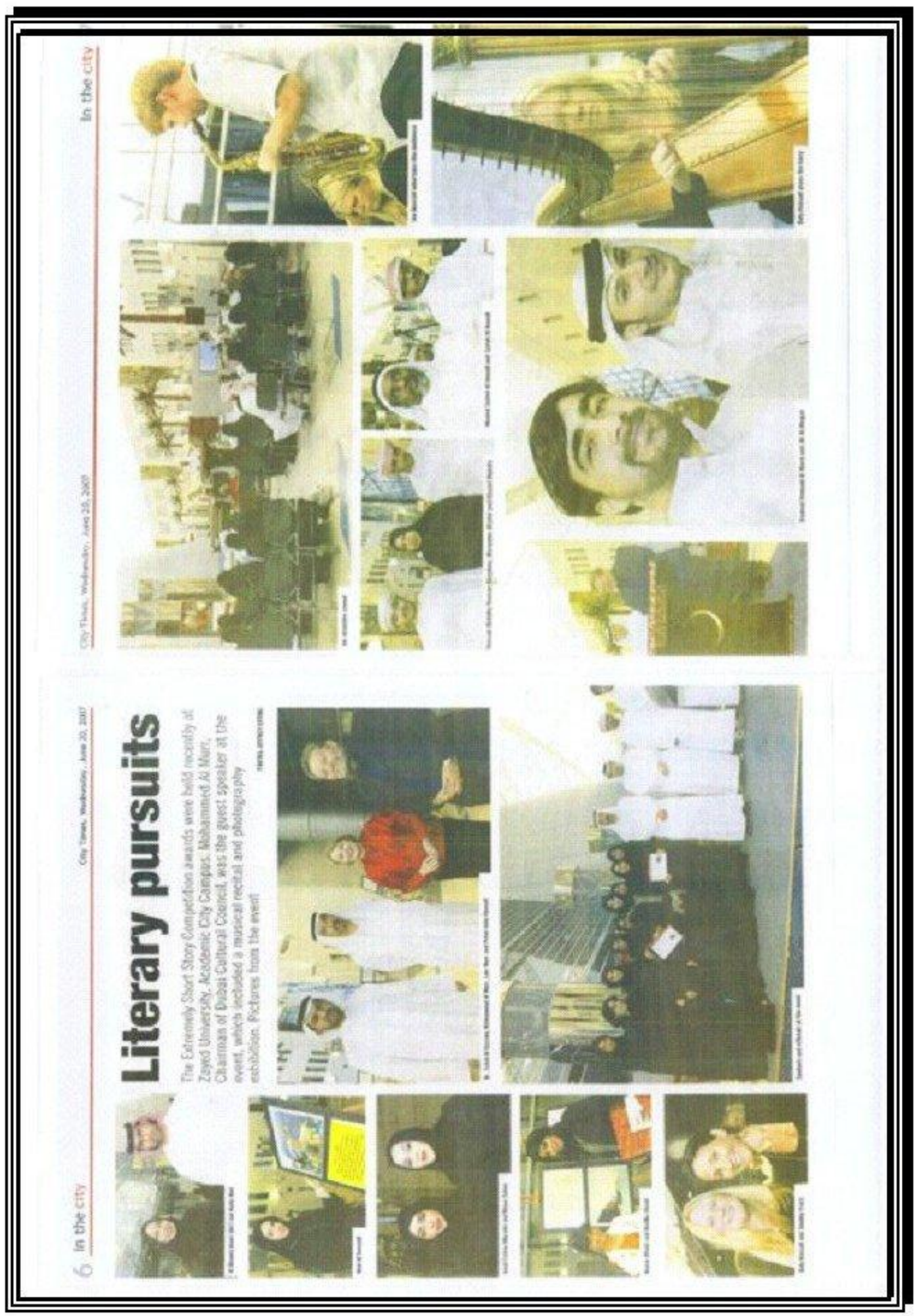

Figure 7: ESSC Awards Evening at Zayed University Dubai showing ESSC Prizewinners with Guest of Honor Mohammad Al Murr (Chairman of Dubai Cultural Council) and the Facets of Emirati Women exhibition (Khaleej Times (2007).

Hassall, P.J. (2011). The Extremely Short Story Competition: fostering creativity and excellence in formal and informal learning contexts in the UAE and internationally. Learning and Teaching in Higher Education: Gulf Perspectives, 8(2). http://Ithe.zu.ac.ae 
This display has developed into what is now known as the 'Facets of Emirati Women UAE Traveling Exhibition [Facets FUTEx]. This exhibition has been on display in the UAE at Mercato Mall in Dubai, and, in a private viewing at Abu Dhabi Mall. It was a prominent feature of the Emirates Airline International Festival of Literature (2009) and was also displayed at the Abu Dhabi International Book Fair (2009). It has also been displayed at the British Council centres in Abu Dhabi and in Dubai, where K. Ryan, one of the project managers, made worksheets (Ryan, 2008) to enable non-native users of English to engage productively with the exhibition. The Facets FUTEx exhibition has been displayed at Zayed University in Abu Dhabi and Dubai and at Higher Colleges of Education from Ras Al Khaimah to Madinat Zayed and Ruwais, but there are still a number of significant centres in the UAE for it to visit.

The resulting anthology, Facets of Emirati Women: World English Voices of the UAE (Hassall, 2009a) was launched at the first Emirates Airlines International Festival of Literature with Brian W. Aldiss, initiator and editor of the Mini Saga Series (Aldiss, 1995-2001) as Guest of Honor. This was also allocated a signing session at the Abu Dhabi Book Fair 2009 and has been made available in bookstores throughout the UAE. Facets of Emirati Women was the first full-color ESSC anthology to be produced.

In the Academic Year 2007/08, the British Council again became a major sponsor of the ESSC. This time, the ESSC was extended throughout the Arabian Peninsula and for the first time included high schools as well as tertiary educational institutions in the Middle East. Involved in this ESSC were seven countries of the Arabian Peninsula: Bahrain, Kuwait, Oman, Qatar, Saudi Arabia, the UAE and Yemen. The ensuing ESSC was held via the web using access codes coupled with liaison personnel to target specific institutions, with procedures coordinated by the ESSC Editor at ZU in the UAE. Winners were chosen for each of the participating countries at secondary and tertiary level and award recipients traveled from Qatar, Yemen and Oman to Zayed University Dubai to receive their prizes at the ESSC Awards Evening, with others being awarded their prizes by the British Council 'in-country'. The overall Regional Winning student-author was awarded the opportunity to attend a short story writing course in the United Kingdom and an article featuring his literary and non-literary experiences on this course appeared in the magazine Time Out Dubai.

\section{ESSC Research}

There is an increasing number of academic studies related to the utilization of the ESSC in tertiary educational contexts. The prospective view offered by Hassall (2006a) suggests the establishment of an International Corpus of Creative English [ICCE] based around the ESSC. This has been influential in promoting further successful experimentation with the Extremely Short Story Competition including: Abu-Wardeh (2006) explaining its utility in teaching language; Fujiwara (2008) investigating creative characteristics of Japanese language learners; La Faye (2007) undertaking action research in the writing class with the ESSC; Miyake (2007), Okaura $(2007,2009)$ and Takeshita (2007) describing successes of the ESSC in Japan. In addition, the ESSC Editors have made efforts to publicize the research benefits of the competition in local radio appearances which are being collected on the ESSC website (http://50words.org) to prompt further interest, reflection and research. Most recently, Matsubara (2011) has written a thesis in Japanese about the Facets of Emirati Women anthology, using ESSC texts written by Emiratis to provide a sociolinguistic introduction to the UAE for Japanese readers.

Hassall, P.J. (2011). The Extremely Short Story Competition: fostering creativity and excellence in formal and informal learning contexts in the UAE and internationally. Learning and Teaching in Higher Education: Gulf 


\section{Future opportunities for the ESSC}

\section{Linguistic analysis of the ESSC corpora from the UAE and further afield}

A major study involving cross-cultural linguistic research is proposed to discriminate between the raw and mediated (edited) UAE texts, which will in turn be compared with the Korean and Japanese texts generated by the Extremely Short Story Competition. When these texts are compiled into substantial corpora gathered from the UAE and overseas, significant outcomes are likely to result that will indicate the relationship between accuracy and creativity when using English across linguistic boundaries.

A two-pronged analysis is planned which will examine both quantitative and qualitative aspects of the texts for cross-linguistic research. The quantitative analysis will consider corpora such as the one shown in Figure 8, which shows a sample from the raw/unmediated corpus of the 'Emiratia' texts. This is arranged here for illustrative purposes only, positioning Crimson Rose's text If you ever wake up (see above) as the first line of the corpus. Statistical research into the frequency of orthographic units is being undertaken with S. Ganesh of the Department of Statistics, Massey University, New Zealand. Two stylometric instruments are to be utilized to accomplish this.

If you ever wake up in the morning, before the sun would rise, you'd see a sight fo Once upon a time, there was a sick kid who loved a famous football player. One da One day, I heard the sound of a small girl when I went to my home. I didn't care be Yesterday, my father told me a funny story about my sister. One day while she was One day I suffered of a bad weather, a bad exam result, my Uncle's sickness and Last year, my partners celebrated my birthday in work. They didn't told me about $t$ One day, I made an accident that hurt my hand. That happened two years ago whe When I was 14 years old, I went to Egypt with my family. I saw my aunt and her chi I went with my family to overland for camping in the UAE last year. My sisters and One day, when I was working in a kids' nursery as an assistant teacher. One of the Last summer my family decided to travel to Australia. When I arriv at Sydney Air $p$ Hey friend, Do you see that palace of happiness over there? Or that lake of joy bes There were a woman in the village. She was very kind woman. But she hadn't child One day, my father traveled. This day was very bad. My brothers played football. Yesterday I had the final exam for level 7. I waked up late and I couldn't reach the Yesterday night I was going to my friend's house. While I was walking I felt that so Jane is a university student. She has everything she needs. A good family, enough I loved this story because I saw this, my self. This story talked about a young child I see small boy sitting in the corner and he is looking for the people in the street. T Last week, I had a simple fight with my best friend because of something a bit stup

Figure 8: Part of the ESSC ZU corpus.

Hassall, P.J. (2011). The Extremely Short Story Competition: fostering creativity and excellence in formal and informal learning contexts in the UAE and internationally. Learning and Teaching in Higher Education: Gulf 
Data Mining is illustrated in Figure 9. This is employed to uncover clusters of descriptive terms that characterize particular corpora. The two major clusters shown here characterize the raw/unmediated Emiratia corpus referred to above.

\begin{tabular}{|c|c|c|c|}
\hline \multicolumn{4}{|c|}{$\begin{array}{c}\text { DATA MINING } \\
\text { Unmediated Corpus }\end{array}$} \\
\hline \# & Descriptive Terms & Freq & Percent \\
\hline 1 & $\begin{array}{l}\text { a, went, in, the, was, } \\
\mathrm{I} \text {, when, of, and, her }\end{array}$ & 171 & $72 \%$ \\
\hline 2 & $\begin{array}{l}\text { but, she, to, that, } \\
\text { me my, with, is, it }\end{array}$ & 65 & $28 \%$ \\
\hline
\end{tabular}

Figure 9: Sample data mining analysis of ESSC corpus data.

Correspondence Analysis [CA] is illustrated in Figure 10. This is used to consider the distribution of orthographic forms to differentiate different corpora from one another. Graphical representation of CA from earlier studies (Hassall, 1998; Hassall \& Ganesh, 1999) is shown here which distinguishes student text gathered in Ras AI Khaimah UAE, from student text gathered in Japan, Korea, Taiwan and Thailand.

Projections of the nineteen most frequent ( $>500)$ word $t$ ypes ont the secondary axis through the Ri'Al goup (Hassall \& Ganesh, 1999)

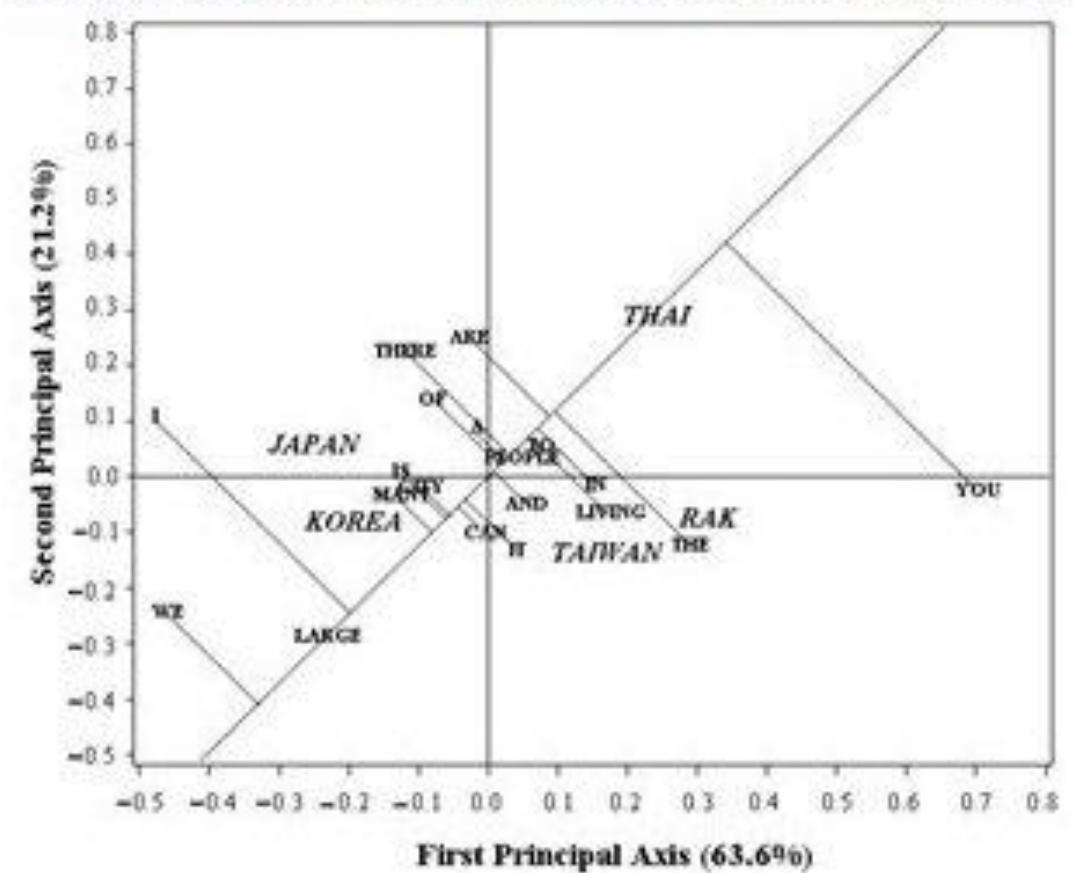

Figure 10: Sample correspondence analysis of ESSC corpus data.

Hassall, P.J. (2011). The Extremely Short Story Competition: fostering creativity and excellence in formal and informal learning contexts in the UAE and internationally. Learning and Teaching in Higher Education: Gulf 
The planned qualitative study is more concerned with research into the topics and situations that are portrayed and investigation of any editing which has been considered necessary for the publication of Emiratia. Similar principles and methodology will be applied to the collection of 50-word stories from countries both near to and far away from the UAE. A website will be made available for archiving parallel student texts collected at tertiary institutions in other countries. Hopefully the project will grow and expand, employing national Emirati students at Zayed University to keep a check on submissions, compile various corpora and help prepare the 50-word stories for archiving, presentation, publication and research.

\section{ESSC project development}

A version of the Facets of Emirati Women exhibition was compiled electronically and formed the basis for the development of a perspective relating to "World Englishes as Art" which was presented at the University of Birmingham, UK (Hassall, 2009b) and at TESOL France Symposium (Hassall \& Collins, 2009). This World Englishes as Art perspective suggests that 50-word-picture combinations or 'diptychs' may provide a powerful innovative artistic form whereby the text and the photograph, as exhibited in the Facets exhibitions, produce a synergy with an affective force which is greater than either of the two elements working separately.

The electronic Facets exhibition has been transformed into a high quality Facets of Emirati Women International Traveling Exhibition (Facets FITEx) utilizing A2 foam art boards and A3 print-outs. Several editions of this exhibition have been compiled with one recently displayed at the British Council Milan, Italy (April, 2011), another being taken to the EAQUALS International Conference in Prague (April, 2011) and another being sent to the Al-Maktoum Institute, Dundee, Scotland. The worksheets compiled by Ryan (2008) have been sent with these Facets FITEx exhibitions to allow students of English as a Foreign/Second Language to use the exhibition as a formal resource, accompanied by their language teachers on class visits or on an individual, informal basis. It is hoped that this exhibition will be sent to more countries interested in finding out about the UAE and its people, and also perhaps instigate the implementation of the ESSC in tertiary educational institutions in other regions of the world.

Selected stories and pictures from the Facets of Emirati Women exhibition have also been sent electronically to Japan where, along with a bilingual preface and the addition of explanatory notes, the stories have been translated by Professor Yuko Takeshita and Professor Fujimi Tanaka from the English into Japanese. This will form the basis for a Facets of Emirati Women Bilingual ESSC E-Book to be made available on the internet, similar to Takeshita \& Tanaka (2010).

The ESSC Development Project is hopeful that some of the published anthologies of ESSC stories may be provided with an Arabic translation which will allow a more inclusive offering for the Arabic-using population of the UAE, similar to the way that the Japanese ESSC anthology (Takeshita \& Tanaka, 2010) is now offered in English and Japanese. It is also hoped that, in the near future, a new initiative will be implemented which has already been run as a pilot project at Zayed University. This project, entitled the Extremely Short Qissa Competition will encourage bilingual Arabic-English student-authors to submit a 50-word piece in Arabic and a 50-word piece in English, together with a picture or photograph as exemplified in Figure 11.

Hassall, P.J. (2011). The Extremely Short Story Competition: fostering creativity and excellence in formal and informal learning contexts in the UAE and internationally. Learning and Teaching in Higher Education: Gulf 


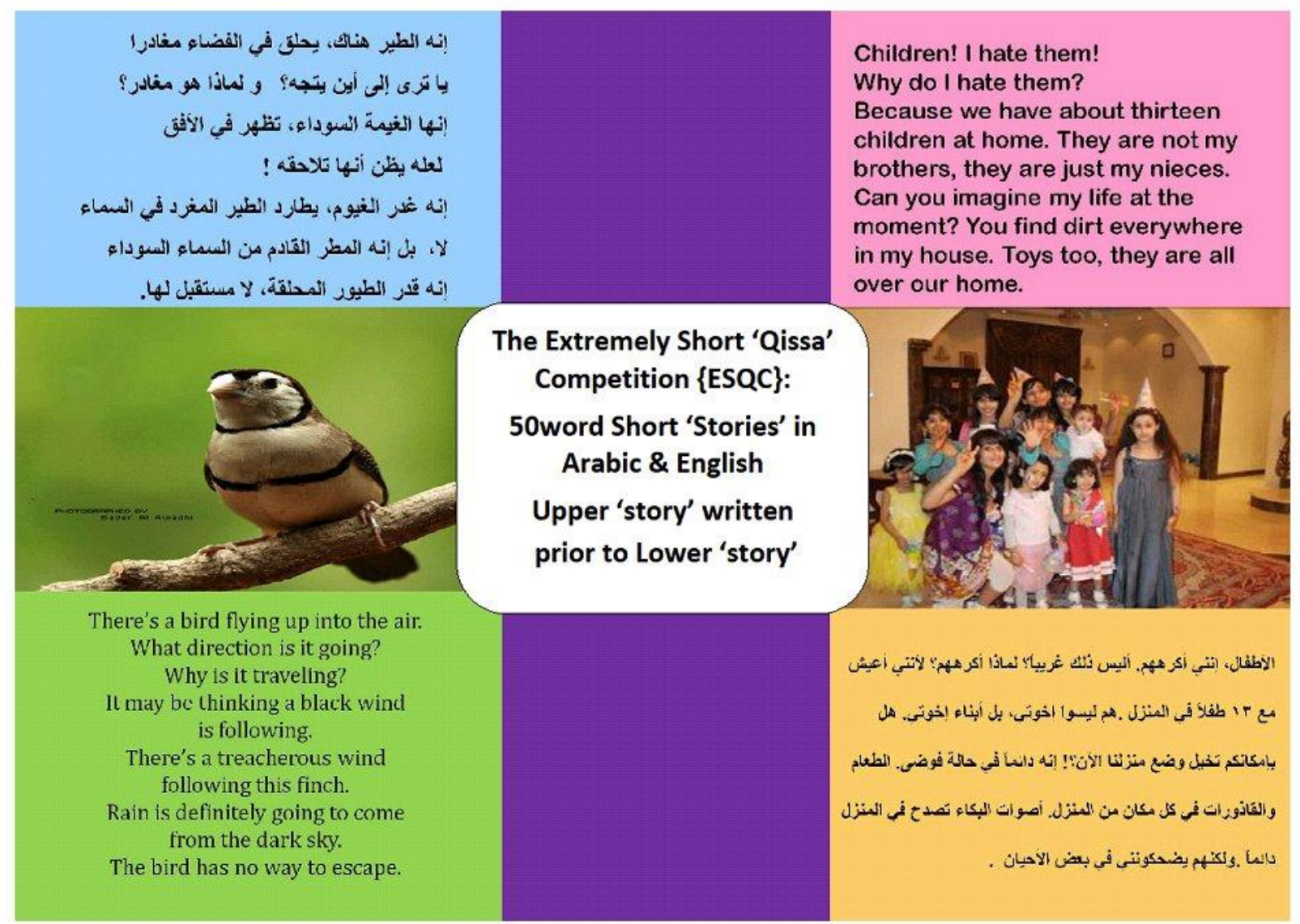

Figure 11: Material from the pilot Extremely Short Qissa Competition (ESQC) (Hassall, Osman, Sellami \& Walsh, 2009).

The ESSC continues to widen its scope and promote international collaboration. For instance, Hassall (2007b), enabled further dissemination of ESSC procedures and output to academics from the Southern Hemisphere centred on Hamilton, New Zealand; Hassall, Hassall \& La Faye (2008) promoted collaboration of academics resident in the Middle East and Far East and the forthcoming Hassall (2011) indicates interest from significant language organisations in Europe. It is hoped that the Extremely Short Story Competition will continue to prove a useful device for fostering creativity and excellence in formal in informal e-language learning contexts in the UAE and internationally.

\section{References}

Abu-Wardeh, P. (2006). Using the Extremely Short Story to teach language. Journal of Asian Englishes, 9 (2), 80-85.

Aldiss, B. W. (Ed.). (1995). Mini Sagas from The Daily Telegraph Mini Sagas. London: Sutton Publishing.

Aldiss, B. W. (Ed.). (2001). The Daily Telegraph Mini Sagas. London: Enitharmon Press.

Edwards, B. (Ed.) 1997. 'Top of the Morning' Book of Incredibly Short Stories. North Shore City, New Zealand: Tandem Press.

Hassall, P.J. (2011). The Extremely Short Story Competition: fostering creativity and excellence in formal and informal learning contexts in the UAE and internationally. Learning and Teaching in Higher Education: Gulf 
Feldhusen, J. F. (1994). Learning and cognition in talented youth. In J. Van Tassel-Baska (Ed.), Comprehensive curriculum for gifted learners (2nd ed.) (pp. 17-28). Boston: Allyn \& Bacon.

Fujiwara, Y. (2008). International Corpus of Creative English, Japan: What are creative characteristics of English used by Japanese learners? University of Louisville, KY: The Intercultural Forum 1 (2). Retrieved from: http://comm.louisville.edu/iic/ICF1(2)2008.html

Hassall, P. J. (1998). Unity in diversity: towards an integrated paradigm of English as an International Language and World Englishes including MAVEN. In H. Lindquist, S. Klintborg, M. Levin \& M. Estling (Eds.) The major varieties of English. Papers from MAVEN 97. (pp., 291-301). Växjö: Acta Wexionensia.

Hassall, P. J. (2004a). WE, TEIL \& ESSC: implications and alternatives for TEFL in the Asian context. Featured Speaker Presentation: 2nd Annual Asia TEFL International Conference "The Power of TEFL: Prospects and Challenges in Asia". Olympic Parktel, Seoul, South Korea. November 5th-7th, 2004.

Hassall, P. J. (2004c). World Englishes and English for Global Communications. In P. Davidson et al. (Eds.), Proceedings of the 9th TESOL Arabia Conference, Dubai. (pp., 224-244).

Hassall, P. J. (2005). Compilation of additional components of the International Corpus of Creative English [ICCE] using the Extremely Short Story Competition [ESSC] Website. Workshop: 3rd Annual Asia TEFL International Conference. Beijing, November 3rd-6th, 2005.

Hassall, P. J. (2006a). Developing an International Corpus of Creative English. World Englishes: 25(1), 131-151.

Hassall, P. J. (2006c). Building the ICCE in the UAE, South Korea and Japan. Presentation: 12th Annual Conference of the International Association for World Englishes [IAWE12] World Englishes in World Contexts Theory and Application, October 7-9, 2006, Chukyo University, Nagoya, Japan.

Hassall, P. J. (2006d). International collaboration to promote literature and linguistics via the Extremely Short Story Competition [ESSC]. Asian Englishes, 8(2), 90-95.

Hassall, P. J. (2007b). Promoting diversity and creativity in TESL/TEFL worldwide through the compilation of the International Corpus of Creative English [ICCE] built around the Extremely Short Story Competition [ESSC]. Paper Presentation: 2nd International Conference on Language, Education and Diversity (LED 2007). 21 - 24 November 2007, University of Waikato, Hamilton, New Zealand.

Hassall, P. J. (2009b). World Englishes as art: the Extremely Short Story Competition [ESS] in Arabia and the Far East. Presentation for MA students studying at the Centre for English Language Studies, University of Birmingham, England. 9, November, 2009. Reported in Birmingham Bite-Size: https://bhamalumni.org/NetCommunity/Page.aspx?pid=796

Hassall, P. J. (2011). Using the Extremely Short Story Competition to enhance creative language learning. Workshop at the Annual Conference of the European Association for Quality Language Services (EAQUALS) 8-9 April, National Technical Library, Prague, Czech Republic.

Hassall, P. J. (Ed.). (2004b). Emiratia: Voices of Zayed University. The English Language Center \& the Student Literature Club, Zayed University, United Arab Emirates.

Hassall, P. J. (Ed.). (2006b). Emiratia: World English Voices of Emirati Women. The Extremely Short Story Development Project, the Student Literature Club \& Zayed University, United Arab Emirates.

Hassall, P. J. (Ed.). (2007a). Pearls of Emirati wisdom: World English voices of the UAE. Extremely Short Story Development Project, Zayed University, United Arab Emirates.

Hassall, P.J. (2011). The Extremely Short Story Competition: fostering creativity and excellence in formal and informal learning contexts in the UAE and internationally. Learning and Teaching in Higher Education: Gulf 
Hassall, P. J. (Ed.). (2009a). Facets of Emirati women: World English voices of the UAE. Extremely Short Story Development Project, Zayed University, United Arab Emirates.

Hassall, P. J. \& Collins, M. (2009). World Englishes as art: the Extremely Short Story [ESS] in Arabia and the Far East. 28th Annual TESOL France Colloquium, Télécom ParisTech, 6-7, November. Slides available at: http://www.tesolfrance.org/Colloquium09/Hassall_Slides.pdf

Hassall, P. J. \& Ganesh, S. (1999). Correspondence analysis of international relative deviance. The on-line conference "Language typology", Web Journal of Formal, Computational \& Cognitive Linguistics, May, 1999. Kazan University: Russian Association of Artificial Intelligence (FCCL). pp. 1-22. Retrieved from: http://fccl.ksu.ru/winter.99/lang_typ/ogl.htm CD-ROM also available from the Editors: FCCL.editors@ksu.ru Honorary Editor: Professor Noam Chomsky.

Hassall, P. J. \& Ganesh, S. (2005). Emiratia Voices of Zayed University: female leaders in story-telling for publication and research. Paper Presentation: Women as Global Leaders Conference March 14-16. United Arab Emirates: Zayed University.

Hassall, P.J. \& Hassall, J. E. (unpublished) Rays of the rising sun. Contributions to the Extremely Short Story Competition [2006] organized in Japan by the Japanese Association for Asian Englishes [JAFAE].

Hassall, P. J., Hassall, S. \& La Faye, B. E. (2008). Designing and Implementing Women's Leadership materials based around the ESSC anthology: "Facets of Emirati Women" Workshop. 2nd Women as Global Leaders Conference, March 10-12. United Arab Emirates: Zayed University.

Hassall, P. J., Osman, E., Sellami, A. \& Walsh, U. (2009). Comparing bilinguals' writing production in Arabic \& English. Presented at the International Conference on Bilingualism and Bilingual Education: Fostering Multiliteracies through education: Middle East Perspectives, organized by The American University of Sharjah MATESOL Program, and the Zayed University Research Excellence Center. December 17-19 2009, American University of Sharjah, UAE.

Khaleej Times (2007, June 20). Literary pursuits. [City Times supplement]. Khaleej Times, pp. 6-7.

La Faye, B. E. (2007). Asking the writing questions? Action research in the Creative Writing Class. Bulletin of Tokai Gakuen University, Nagoya, 11(B), 108-119.

Matsubara, N. (2011, forthcoming). A perspective on UAE women in the 21st Century. (Written in Japanese). Tokyo: The Middle East Research Institute of Japan. Journal of Middle Eastern Studies, 511(1), 113-23.

Miyake, H. (2007). University students' responses to the ESSC. International Conference on Diversity, Harmony and Intercultural Communication. June 22-24, Harbin Institute of Technology, China.

Okaura, Y. (2007). Relevance-theoretic approach to some characteristics of ESS works in Japan. University of Louisville, KY: The Intercultural Forum, 1(2). Retrieved from: http://comm.louisville.edu/iic/ICF1(2)2008.html

Okaura, Y. (2009). Grammatical characteristics of good 50-word essays by Japanese students of English: optimal relevance through the formation of explicatures. University of Louisville, KY: The Intercultural Forum, 18(2): 214-218. Retrieved from: http://www.uri.edu/iaics/content/2009v18n2/16\%20Yoshiyuki\%200kaura.pdf

Ryan, K. (2008). Worksheets for the Facets of Emirati Women UAE \& International Traveling Exhibitions. Published in-house at the British Council Dubai, UAE.

Hassall, P.J. (2011). The Extremely Short Story Competition: fostering creativity and excellence in formal and informal learning contexts in the UAE and internationally. Learning and Teaching in Higher Education: Gulf 
Takeshita, Y. \& Tanaka, F. (2010). The Extremely Short Story Competition. (Bilingual E-book in English/Japanese). Tokyo: The Japanese Association For Asian Englishes (JAFAE). http://wepublish.jp/products/detail.php?product_id=605

Takeshita, Y. (2006). Make it extremely short, please! Asian Englishes, 9 (1), 104-106. Retrieved from: http://essc.fit.ac.jp/en/file/9-1_essay.pdf

Takeshita, Y. (2007). The Extremely Short Story Competition (ESSC): a successful case in Japan. International Conference on Diversity, Harmony and Intercultural Communication. June 22-24, Harbin Institute of Technology, China.

Zayed University (2007). Express yourself! The Extremely Short Story Competition enters its third year. Zawaya: the official magazine of Zayed University. United Arab Emirates. Retrieved from http://www.zu.ac.ae/zawaya/0101/0113.pdf (English)/ http://www.zu.ac.ae/zawaya/0101/0113A.pdf (Arabic).

${ }^{1}$ Perhaps the most well-known Emirati to be translated into English is Mohamed Al Murr, who has written two well known collections of short stories entitled Dubai Tales (1990, Trans: P. Clark. London: Forest Books) and The Wink of the Mona Lisa (1994, Trans: J. Briggs. Dubai: Motivate).

Hassall, P.J. (2011). The Extremely Short Story Competition: fostering creativity and excellence in formal and informal learning contexts in the UAE and internationally. Learning and Teaching in Higher Education: Gulf 